\title{
EDITORIAL
}

(English version below/ Versão em portugues ao final)

\section{Haciendo un pensar}

\begin{abstract}
Aldo Parra-Sánchez ${ }^{1}$
Nuestra revista tiene dentro de sus políticas editoriales dar visibilidad a grupos, temáticas y tendencias emergentes en latinoamericana, tal como se hizo en números dedicados a la modelación matemática, la relación raza/poder, o a los investigadores del grupo de Etnomatemática de la UNESP de Rio Claro, Brasil. Continuando esa tradición, en esta ocasión pretendemos dar registro del momento de fulgor que están experimentando los enfoques sociopolíticos de la educación matemática en Colombia, visibilizando a nivel internacional la comunidad de autores y escuelas responsables de tal expansión. Este dinamismo no se da apenas en la difusión de referenciales teóricos de autores internacionales pioneros reconocidos en el campo y una consecuente implementación escolar local de tales ideas, sino que se manifiesta en la apropiación, reelaboración, crítica y expansión a nivel teórico y metodológico.

Si bien en distintas partes del mundo como Brasil, India o Suráfrica conceptualizaciones como la educación matemática crítica, las matemáticas para la justicia social y otras afines están siendo interpretadas y desarrolladas, Colombia constituye un terreno bastante fértil para que estas problematizaciones germinen de manera particular y propia, dadas las complejas situaciones de violencia y explotación que históricamente han marcado la construcción de esta nación. De igual modo, la coyuntura reciente de un acuerdo de paz y su azarosa implementación demarcan una etapa especialmente propicia para imaginar y explorar los diversos roles de la educación matemática en la re-construcción de la sociedad. Un escenario de postconflicto exhorta a indagar las formas en que la educación hace (ir)relevante el saber matemático como herramienta para la participación activa, consciente y soberana de los ciudadanos y comunidades en la consecución de su propio buen vivir.
\end{abstract}

\footnotetext{
${ }^{1}$ Profesor Universidad del Cauca, Popayán, Colombia. E-mail: aldo@etnomatematica.org
} 
La atención prestada por los investigadores colombianos en educación matemática a estas situaciones es creciente, y puede constatarse con la producción de 10 tesis doctorales bajo este enfoque en los últimos 5 años, cifra gigantesca para la producción habitual del país. Esto demarca una nueva fase dentro del proceso de consolidación de una comunidad académica activa, que inició a principios del siglo XXI por investigadoras como Paola Valero y Gloria García, continuado con el trabajo de grupos de investigación como EdUtopía en la Universidad Distrital, Educación matemática, diversidad y subjetividades en la Universidad Pedagógica Nacional y Universidad Distrital (Edumadys) y Matemáticas, Educación y Sociedad de la Universidad de Antioquia (MES).

Esta comunidad hace una expansión del campo investigativo de educación matemática colombiana, tanto a nivel de las temáticas, como de los espacios y actores a estudiar, y concomitante a ello, una innovación en los referentes teóricos y estrategias metodológicas usadas. Esto irremediablemente conduce a discusiones acerca de los fines de la investigación misma, las formas de socialización y sus impactos, albergando estrategias inexploradas por enfoques más tradicionales de investigación.

Presentamos entonces a consideración de nuestros lectores los adelantos más recientes de esta creciente comunidad colombiana en dos partes. En este primer número especial publicaremos textos con los avances de seis trabajos doctorales que evidencian cómo se está "haciendo un pensar" colombiano acerca de cuestiones críticas de orden social y político de la educación matemática. Un segundo número especial incluye los debates acerca de las potencialidades, limitaciones e implicaciones de estas iniciativas académicas, estaremos entonces "pensando un hacer", para ello invitamos autores nacionales e internacionales a aportar lecturas transversales de este conjunto de trabajos.

La iniciativa de publicar estas producciones busca propiciar diálogos en varios niveles, siendo el más inmediato el de los autores con un público amplio y anónimo. Otro nivel es el que se da entre los autores, que realizaron la evaluación académica de los textos a través de lectura cruzada entre pares, lo que les permitió intercambiar opiniones, abordajes y concepciones acerca de las cuestiones sociales y políticas de la educación matemática. Un tercer nivel de diálogo se dará entre académicos radicados en Colombia y fuera de ella, 
Parra-Sanchez, A. (2020). Haciendo un pensar. Revista Latinoamericana de Etnomatemática, 13(4), 1-7. DOI: $10.22267 /$ relatem.20134.76

examinando el proceso de criollización evidenciado en estas "conversiones, perversiones, subversiones y diversiones" a los enfoques de índole critico y político. Este último nivel sirve para posicionar y ubicar la multiplicidad de abordajes locales con respecto a corrientes investigativas internacionales.

Por lo anteriormente expuesto, esperamos que este número sea un paso cierto en la transición de una educación matemática en Colombia hacia una educación matemática colombiana.

\section{Doing a way of thinking}

One of the main editorial policies of this journal is to give visibility to groups, themes and emerging trends in Latin America. This has been evident with several special issues, dedicated to mathematical modelling, the relation race/power, or the researchers of the Ethnomathematics group of Unesp in Rio Claro, Brazil. Continuing that tradition, on this occasion we use our spotlight to share the momentum that sociopolitical approaches to mathematics education in Colombia are gaining, making visible at an international level the community of authors and groups leading such turn. This dynamic trend does not occur only as the diffusion of theoretical references of international pioneer authors recognized in the sociopolitical field and a consequent local school implementation of such ideas, but it is manifested in the appropriation, re-elaboration, criticism and expansion at a theoretical and methodological level.

In several parts of the world, like Brazil, India or South Africa conceptualizations such as critical mathematics education, mathematics for social justice and related others are being interpreted and developed. In particular, Colombia constitutes a quite fertile ground for these problematizations to germinate in a singular and rooted way, given the complex situations of violence and deprivation that have historically marked the constitution of this nation. Similarly, the recent conjuncture of a peace agreement and its hazardous implementation mark an especially propitious stage to imagine and explore the various roles of mathematics education in the rebuilding of society. A post-conflict scenario encourages us to investigate the ways in which education makes mathematical knowledge (ir)relevant as a tool for the 
active, conscious and sovereign participation of citizens and communities in the achievement of their own well-being.

The attention paid by Colombian researchers in mathematics education to these situations is growing, and it can be verified with the production of 10 doctoral theses under this approach in the last 5 years, a gigantic figure for the usual production of the country. This marks a new phase within the process of consolidating an active academic community, which began at the beginning of the 21th century by researchers such as Paola Valero and Gloria García, continued with the work of research groups such as EdUtopía at the Universidad Distrital; Mathematics education, diversity and subjectivities at the Universidad Pedagógica Nacional (Edumadys) and Mathematics, Education and Society at the Universidad de Antioquia (MES).

This community expands the Colombian research field of mathematics education, both at the level of the themes, as well as the scenarios and actors to be studied, and concomitant to this, an innovation in the theoretical references and methodological strategies used. This inevitably leads to discussions about the purposes of the research itself, the forms of socialization and their impacts, allowing new strategies that had no space within more traditional research approaches.

We present to our readers' consideration the most recent advances of this growing Colombian community in two parts. In this first special issue we will publish texts with the results of recent doctoral theses that show how Colombians are "doing a way of thinking" about critical issues of a social and political nature in mathematics education. A second special issue will include debates about the potentialities, limitations and implications of these academic initiatives, we will then be "thinking a way of doing". To do so, we invited national and international authors to contribute with transversal readings of this handful of experiences.

The initiative to publish these research projects seeks to promote dialogues at various levels, the most immediate being that of the authors with a broad and anonymous public. Another level is the one that occurs between the authors, who carried out the academic evaluation of the texts through cross-reading between peers, which allowed them to exchange opinions, approaches and conceptions about the social and political issues of mathematics education. 
Parra-Sanchez, A. (2020). Haciendo un pensar. Revista Latinoamericana de Etnomatemática, 13(4), 1-7. DOI: $10.22267 /$ relatem. 20134.76

A third level of dialogue will take place between academics based in Colombia and abroad, they examine the process of creolization evidenced in these "conversions, perversions, subversions and diversions" to critical and political approaches. This last level serves to position and locate the multiplicity of local approaches regarding to international research trends.

Due to the above, we hope that this number will help in the transition from a mathematics education in Colombia to a Colombian mathematics education.

\section{Fazendo um pensar}

Nossa revista tem dentro de sua política editorial dar visibilidade a grupos, temas e tendências emergentes na América Latina, como foi feito em números dedicados à modelagem matemática, à dupla raça/poder, ou aos pesquisadores do grupo de Etnomatemática da UNESP de Rio Claro, Brasil. Dando continuidade a essa tradição, pretendemos nesta ocasião registrar o momento brilhante que estão vivenciando as abordagens sociopolíticas da educação matemática na Colômbia, tornando visível internacionalmente a comunidade de autores e escolas responsáveis por tal expansão. Esse dinamismo não ocorre apenas na disseminação de referenciais teóricos de autores pioneiros internacionais reconhecidos na área e uma consequente implementação escolar local de tais ideias, mas se manifesta na apropriação, reelaboração, crítica e ampliação a um nível teórico e metodológico.

Em várias partes do mundo, como Brasil, Índia ou África do Sul, conceituações como educação matemática crítica, matemática para justiça social e outros relacionados estão sendo interpretados e desenvolvidos. Em particular, a Colômbia constitui um terreno bastante fértil para que essas problematizações germinem de forma singular e enraizada, dadas as complexas situações de violência e privação que historicamente marcaram a constituição desta nação. Da mesma forma, a recente conjuntura de um acordo de paz e a incertidão da sua implementação marcam uma fase especialmente propícia para imaginar e explorar os vários papéis da educação matemática na reconstrução da sociedade. Um cenário de pós- 
conflito nos estimula a investigar as formas pelas quais a educação torna o conhecimento matemático em (des)relevante como ferramenta para a participação ativa, consciente e soberana de cidadãos e comunidades na conquista de seu próprio bem-estar.

A atenção dispensada por pesquisadores colombianos em educação matemática a essas situações é crescente, o que pode ser verificado com a produção de 10 teses de doutorado sob esse enfoque nos últimos 5 anos, um número gigantesco para a produção usual do país. Isso marca uma nova fase no processo de consolidação de uma comunidade acadêmica ativa, iniciado no início do século XXI por pesquisadores como Paola Valero e Gloria García, e continua com o trabalho de grupos de pesquisa como EdUtopía na Universidad Distrital; Educação matemática, diversidade e subjetividades na Universidad Pedagógica Nacional (Edumadys) e Matemática, Educação e Sociedade na Universidad de Antioquia (MES).

Esta comunidade expande o campo colombiano de pesquisa em educação matemática, tanto no nível dos temas, como dos cenários e atores a serem estudados e, concomitante a isso, faz uma inovação nos referenciais teóricos e estratégias metodológicas utilizadas. Isso inevitavelmente leva a discussões sobre os propósitos da pesquisa em si, as formas de socialização e seus impactos, permitindo novas estratégias que não tinham espaço nas abordagens de pesquisa mais tradicionais.

Apresentamos à consideração de nossos leitores os avanços mais recentes desta crescente comunidade colombiana em duas partes. Neste primeiro número especial publicaremos textos com os resultados de recentes teses de doutorado que mostram como os colombianos estão "fazendo um pensar" sobre questões críticas de natureza social e política na educação matemática. Um segundo número especial incluirá debates sobre as potencialidades, limitações e implicações dessas iniciativas acadêmicas, estaremos então "pensando um fazer". Para tanto, convidamos autores nacionais e internacionais a contribuir com leituras transversais deste punhado de experiências.

A iniciativa de publicar estes projetos de investigação visa promover o diálogo a vários níveis, sendo o mais imediato o dos autores com um público amplo e anónimo. Outro nível é o que ocorre entre os autores, que realizaram a avaliação acadêmica dos textos por meio de leitura cruzada entre pares, o que lhes permitiu trocar opiniões, abordagens e concepções 
Parra-Sanchez, A. (2020). Haciendo un pensar. Revista Latinoamericana de Etnomatemática, 13(4), 1-7. DOI: $10.22267 /$ relatem. 20134.76

sobre as questões sociais e políticas da educação matemática. Um terceiro nível de diálogo acontecerá entre acadêmicos baseados na Colômbia e no exterior, eles examinam o processo de crioulização evidenciado nessas "conversões, perversões, subversões e diversões" das abordagens críticas e políticas. Este último nível serve para posicionar e localizar a multiplicidade de abordagens locais em relação às tendências da pesquisa internacional.

Devido ao exposto, esperamos que este número ajude na transição de uma educação matemática na Colômbia para uma educação matemática colombiana. 